\title{
高熱負荷を受けるコンクリート構造部材の 温度特性に関する基礎的研究
}

\author{
黒田一郎 ${ }^{1} \cdot$ 日野伸一 ${ }^{2} \cdot 太$ 太田俊昭 ${ }^{3}$ \\ ${ }^{1}$ 正会員 工博 九州大学助手 工学部建設都市工学科( $=812$ 福岡市東区箱崎6-10-1) \\ ${ }^{2}$ 正会員 工博，九州大学助教授 工学部建設都市工学科( 7812 福岡市東区箱崎6-10-1) \\ ${ }^{3}$ 正会員 工博 九州大学教授 工学部建設都市工学科( $=812$ 福岡市東区箱崎6-10-1)
}

\begin{abstract}
本研究は $100^{\circ} \mathrm{C} \sim 1000^{\circ} \mathrm{C}$ 範囲の高温下に曝された鉄筋コンクリートや鋼・コンクリート合成部材など の鋼材を有するコンクリート構造物の温度特性を明らかにすることを目的としたものである.すなわち, まず, 高温下におけるコンクリートの材料定数を正確に把握するための実験装置を製作し，それを用いた 一連の実験より，材料定数の温度依存性に関する知見を得る. 次に, 鉄筋コンクリートはりおよび立体卜 ラス型ジベル付鋼板・コンクリート合成はりを対象とした加熱実験を行ない, 複合構造部材としての温度 特性について検討するとともに,この種の複合構造体に適用し得る埋め込み鉄筋モテルを導入した有限要 素解析法の適用性についても検討を加えるものである.
\end{abstract}

Key Words : heat conduction, thermal stress, steel-concrete composite beam, finite element analysis, embedded model for reinforcements

\section{1. まえがき}

現在，鉄筋コンクリートや，鋼・コンクリート合 成構造などの構造部材が, 各種の土木・建築構造物 に幅広く利用されている. 通常, これらの構造物の 設計は常温条件下での保有耐荷力や変形性能を基準 として行なわれている. したがって，火災などの突 発的な事故によって高温状態に曝された構造物の耐 荷力や劣化等の安全性については検討されることは 稀である. しかしながら, 原子炬格納容器や石油, ガス等可燃性のある貯蔵構造物, さらには宇宙口ケ ット発射施設などの構造物については，高温に曝さ れるような極限状態に対する安全性の検討が設計上 必要亡考えられる. また, 火災に遭遇した橋梁や建 築構造物などの被害の程度や残存耐荷性能の判定を 迫られる場合もある. そのため, 高温下に曝された 場合のコンクリートの力学特性や熱伝導特性などの 信頼性の高いデータの蓄積と, それに基づく鋼材と コンクリートから成る複合構造体の熱伝導・温度応 力の解明が重要となる.

ところで, コンクリート構造物の熱伝導・温度応
力に関する既往の研究の主流は, 水和熱を生じるマ スコンクリートや, P C C Vなどの原子炉格納容器 などを対象として行なわれてきた. マスコンクリー 卜の水和熱による温度応力についての研究としては, ダム嵩上げ時の温度応力に関する研究や, 橋脚フー チングの打設時の温度応力に関する研究が1960年代 から盛んに行なわれている. たとえば，田辺ら ${ }^{1)}$ は ダム嵩上げ時の温度応力について実測するとともに, その有限要素法による解析手法について言及してい る. また, 森本ら ${ }^{2)}$ は橋脚フーチングの温度ひび割 れ予測についての興味ある知見をまとめている.さ らに, コンクリートダムの温度応力制御法としては, プレクーリング3) やパイプクーリング4) に関する研 究がある.これらの温度制御法はコンクリートダム のみならず基礎スラブや橋脚フーチングの温度応力 制御のためにも利用されている.これらのマスコン クリートに関する研究では, コンクリート構造物に 熱を供給する熱源はコンクリートの水和熱に限られ ているものがほとんどであり，このため扱う温度範 囲は常温から高くても $90^{\circ} \mathrm{C}$ 程度までに限られている.

一方, P C C Vなどの原子炉格納容器に関する研 究としては, たとえば秋野ら ${ }^{5)}$, 吉田 ${ }^{6)}$, 阿部ら 
の研究を挙げることができる.こ.れらの研究では, 地震荷重などの温度以外の荷重と温度応力が同時に 作用した際の挙動などについても研究がなされてい る. また, 原子炉格納容器は常時高温に曝されてい ることから, コンクリートの高温下でのクリープが 温度応力性状に及ぼす影響についても研究がなされ ている ${ }^{8)}$. 原子炉格納容器に作用する温度荷重とし ては通常運転時で約 $50^{\circ} \mathrm{C}$, 事故時として最大で約 $140^{\circ} \mathrm{C}$ 程度の温度が想定されている ${ }^{8)}$.これらの研 究分野以外に, 液化ガスタンクに関する研究 ${ }^{10)}$ が あるが, これらの研究ではコンクリート構造物が高 温に懪されることを想定していない.

設計時点で想定されていない予期せぬ高温に曝さ れるコンクリート構造物に関する研究としては, コ ンクリートの耐火性状についての研究 ${ }^{11}$ がある.

これらの研究では, 数百 ${ }^{\circ} \mathrm{C}$ 達する高温に曝された コンクリートの材料定数の測定実験や, 合成スラブ の耐火実験などが行なわれている. また, 偶然火災 にあったコンクリート橋の事例も報告されてい $3^{122}$.これらの耐火性状に関する研究は実験のみ によるものがほとんどである.

以上のように, コンクリート構造物の熱伝導・温 度応力に関する既往の研究の主流は $100^{\circ} \mathrm{C}$ 程度の温 度レベルのものに限られており, それ以上の温度レ ベルに対する研究は極めて少ない状況にある. また， これらの研究では無筋コンクリートを対象としたも のがほとんどであり，鋼材の影響を考虑したコンク リート構造物の高温レベルにおける熱伝導・温度応 力性状については未だ十分に研究されていないのが 現状である.

そこで本研究は, $100^{\circ} \mathrm{C} \sim 1000^{\circ} \mathrm{C}$ 範囲の高温下 に曝された鉄筋コンクリートや鋼・コンクリート合 成部材などの鋼材を有するコンクリート構造物の温 度特性を明らかにすることを目的としたものである。 著者らは過去に, 材料定数の温度依存性を考慮しな い解析について既に発表している ${ }^{13)}$. 本報では, まず, 高温下におけるコンクリートの材料定数を正 確に把握するための実験装置を製作し，それを用い た一連の実験より, 材料定数の温度依存性に関する 知見を得る. 次に, 鉄筋コンクリートはりおよび立 体トラス型ジベル付鋼板・コンクリート合成は

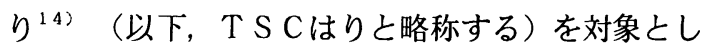
た加熱実験を行ない, 複合構造部材としての温度 分布; 高温下でのひずみ分布等の温度特性につい て検討するとともに，この種の複合構造体に適応し 得る埋め込み鉄筋モデル ${ }^{15)}$ ，16) 導入した有限要 素解析法の適用性についても検討を加えるものであ る.

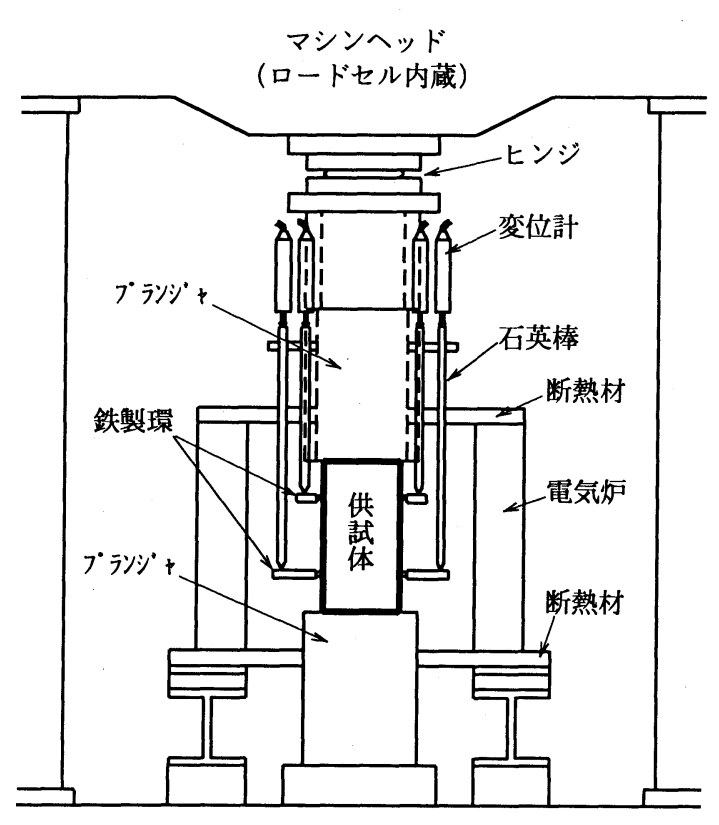

マシンテーブル

図-1 コックリートの高温下でのヤング係数測定実験装置

\section{2. 高温下におけるコンクリートのヤング係 数, 熱伝導率}

著者らは, 先にコンクリートのヤング係数や熱伝 導率の温度依存性が熱伝導・温度応力特性に大きな 影響を及ぼすことを解析的に明らかにしている ${ }^{17)}$. 従って, コンクリート構造物の熱伝導 ・温度応力解 析の際にはこれら材料定数の温度依存性を考虑する 必要があり, そのデー夕を得るため, コンクリート 円柱供試体の高温下でのヤング係数測定装置を試作 し，標準的な普通コンクリートを対象とした一連の 実験を行なうとともに，熱伝導率測定実験をも並行 して行なう。

\section{（1）ヤング係数の温度依存性}

コンクリートのヤング係数の温度による変化を調 べるために，一定高温下で 1 軸圧縮載荷することに より円柱供試体のヤング係数を測定し得る特殊な装 置の製作を行なった，その装置を図-1および写真-1 に示す.

本装置では，コンクリート供試体は断熱材の円筒 容器内に設置され, 電熱線により側面から一様に加 熱される. 数時間の加熱後, 一定の高温を保った状 態(定常温度状態)で, 上下面からコンクリート性プ ランジャー $(\phi 15 \mathrm{~cm})$ を介して 1 軸圧縮し，その時の 


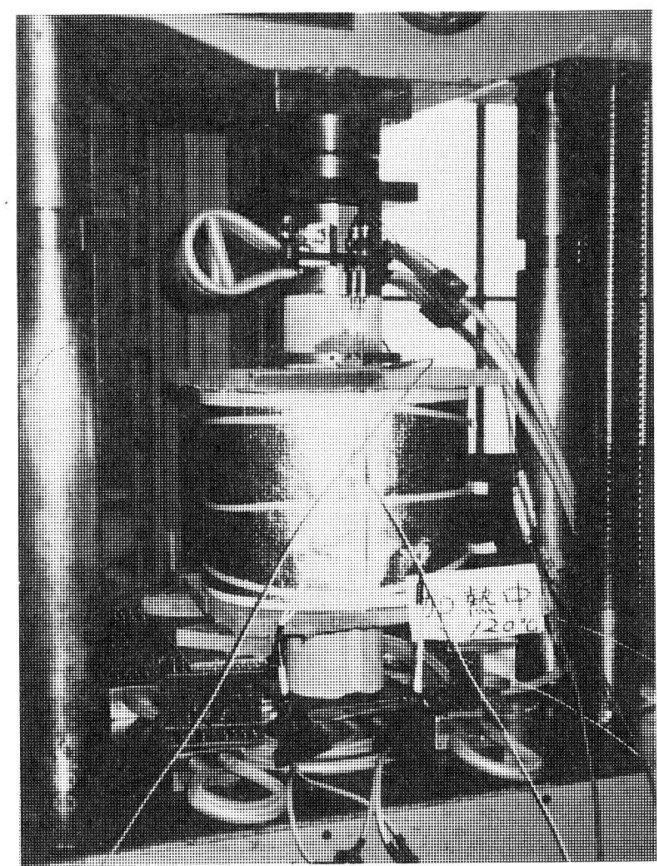

写真-1 コンクリートの高温下でのヤング係数测定実験装置

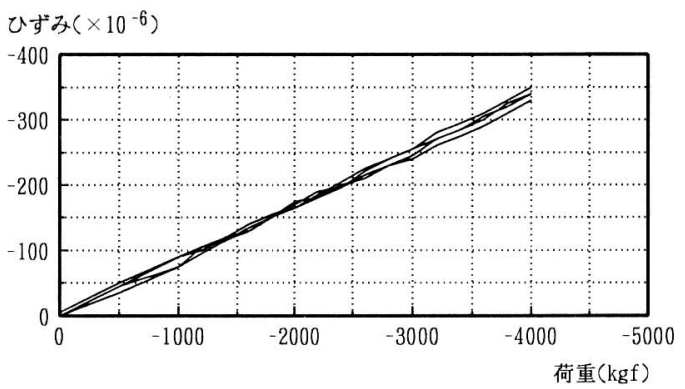

図-2 荷重とひずみの関係の一例 $\left(420^{\circ} \mathrm{C}\right.$ 加熱 1 体目供試体)

表-1 コンクリートの示方配合と設計強度

\begin{tabular}{|c|c|c|c|c|c|c|}
\hline \multirow{2}{*}{ 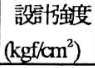 } & \multirow{2}{*}{$\begin{array}{c}\text { 水好外比 } \\
(\%)\end{array}$} & \multicolumn{5}{|c|}{ 単位重量 } \\
\hline & & 妇外 & 水 & 紐骨材 & 粗骨材 & AE減水剂 \\
\hline 300 & 50 & 326 & 163 & 781 & 1086 & 0.815 \\
\hline
\end{tabular}

縦ひずみを鉄製環と石英ガラス棒を介して電気式変 位計(感度 $1 / 1000 \mathrm{~mm}$ )により測定する. 図-2に測定に よって得られた荷重－縦ひずみ関係の一例を示す. 所要のコンクリートのヤング係数はこれらの荷重一 縦ひずみ関係を用いて算出する。一般的には圧縮強 度の $1 / 3$ の割線弾性係数が用いられているが, 本 実験では装置の構造上の制約から 25〜 $65 \mathrm{kgf} / \mathrm{cm}^{2}$ の

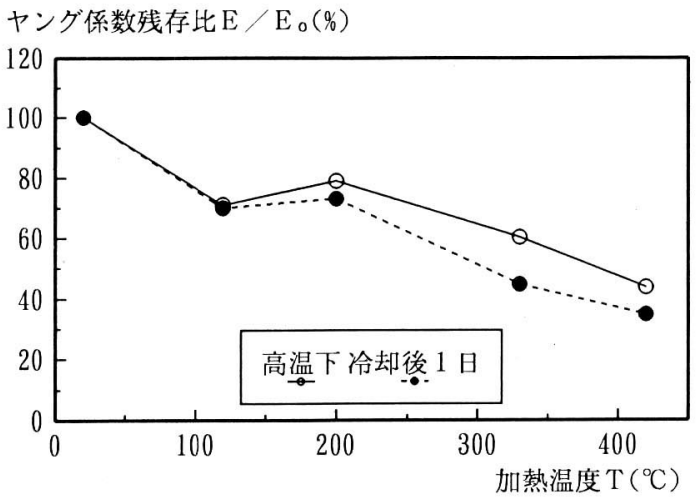

図-3 ヤング係数残存比と加熱温度との関係

間の応力レベルにおける接線弾性係数として算出す ることとする.

供試体加熱表面における加熱温度は $120^{\circ} \mathrm{C}, 200^{\circ} \mathrm{C}$, $330^{\circ} \mathrm{C}$ おび $420^{\circ} \mathrm{C}$ の 4 ケースとし， 加熱する温度上 昇速度はいずれの場合も $2 \sim 3^{\circ} \mathrm{C} / \mathrm{min}$ 程度とした.こ の程度の温度上昇速度では供試体内部と表面の温度 差がほとんどないことは予め熱電対を埋め込んだ円 柱供試体を用いた予備実験によって確認済みである。 また，炉内各部の温度分布もほぼ均一であることが， 炬内数ヶ所に配した熱電対によって確かめられてい る. 圧縮試験は同一の温度レベルにつき数体の供試 体を用いて行なった．供試体は $\phi 10 \times 20(\mathrm{~cm})$ の円柱 供試体であり, $W / C$ (水セメント比) $50 \%$ の配合のも のを使用した．表-1に供試体の示方配合と設計基準 強度を示す. 使用した細骨材は粗粒率 2.70 , 表乾比 重2.58の海砂であり, 粗骨材は表乾比重2.75の頁岩 である.なお実験は、コンクリート打設後 10 週間気 乾養生した後に行なった.

以上のようにして求めた高温下におけるコンクリ 一トのヤング係数 $E$ の, 常温時のヤング係数 $E$ 。 に対する残存比 $E / E_{o}$ と加熱温度 $T\left({ }^{\circ} \mathrm{C}\right)$ との関 係を図-3の実線で示す. 高温下でのヤング係数は $120^{\circ} \mathrm{C}$ 加熱で常温時の $70 \%, 200^{\circ} \mathrm{C}$ 加熱で70 80\%, $420^{\circ} \mathrm{C}$ 加熱で $50 \%$ 程度まで低減しており，温度が高 くなるにつれてヤング係数が低減している. しかし， ヤング係数と温度との関係は完全な比例関係ではな く, $120^{\circ} \mathrm{C}$ 前後でヤング係数が大幅に低減している. 以上，本実験より得られた両者の関係を最小 2 乗法 によって定式化すれば次式のようになる.

$$
E / E_{o}=1.02 \times 10^{2} \times e^{-0.00185 T}
$$




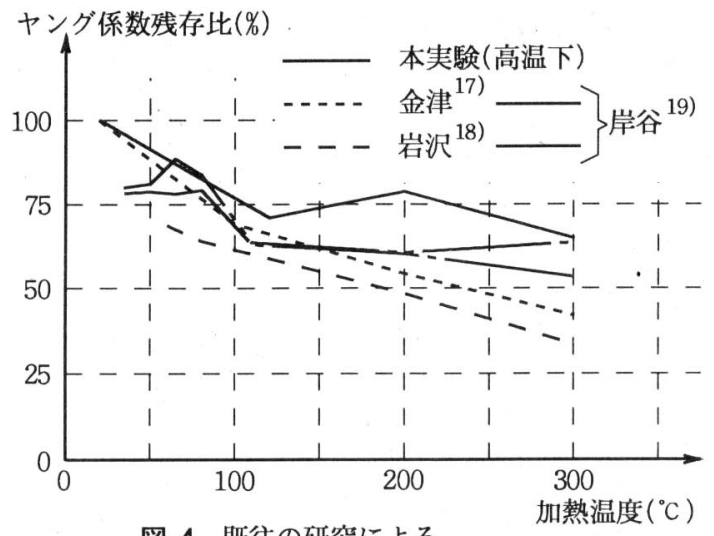

図-4 既往の研究による ヤング係数と加熱温度との関係

既往の研究によれば加熱温度が高くなるにつれて ヤング係数が漸減すると報告したもの(図-4 ${ }^{182}$, 197) や, $100^{\circ} \mathrm{C}$ 付近でヤング係数が常温よりも低減する ものの $100^{\circ} \mathrm{C} \sim 200^{\circ} \mathrm{C} て ゙$ 顕著な低減傾向が認められな いとしたもの(図-4 $\left.{ }^{200}\right)$ もあり，未だ定説化されて いない状況にある。これらの研究では温度上昇に伴 うヤング係数の低減の原因を, 骨材とセメントペー ス卜の間の線膨張係数の差による組織弛緩や, 水分 の移動・逸散に起因する物理的・化学的変化で説明 している ${ }^{21)}$ 。本実験の結果を基にする限り，水の 沸点である $100^{\circ} \mathrm{C}$ 付近でヤング係数が大きく低減し ていることから, 水分の移動・逸散に起因する変化 の影響が大きいと見るべきであろう.

加熱試験後の供試体は, 常温 $\left(\right.$ 約 $\left.20^{\circ} \mathrm{C}\right)$ で 1 日かけ て自然冷却した後, 高温下での測定と同一の装置を 用いて常温下でのヤング係数を測定した. このよう にして求められた冷却直後( 1 日後)のヤング係数残 存比 $E / E_{0}$ と温度 $T$ との関係を図-3の破線で示 す. 図から, 冷却直後のヤング係数の方が高温下で のヤング係数よりも小さくなっていることがわかる. 既往の研究報告では, 冷却後のヤング係数を高温下 でのヤング係数として代用しているものも多い.し かし, 本実験の結果は高温下のヤング係数と泠却後 のヤング係数との間に明らかな差があることを示し ている.

\section{(2)熱伝導率の温度依存性}

コンクリートはその内部に多くの空陌を持ち, 自 由水や結晶水等様々な形で水分を含んでおり, コン クリートの熱伝導現象はこれらの水分の移動や気化 熱等の影響を受けることになる. 特にコンクリート の熱伝導率は, コンクリート自身の熱伝導率とこれ らの影響が合成されたものであるため, 温度による

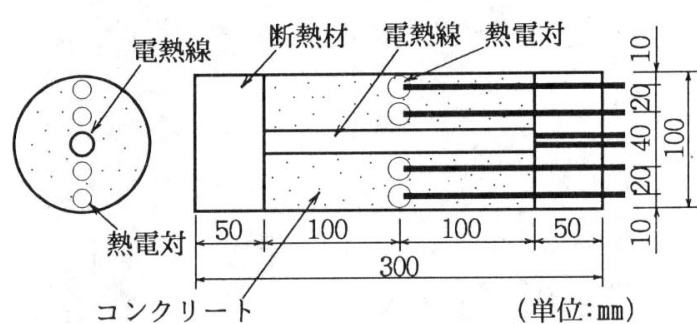

図-5 コンクリートの熱伝導率测定に用いた供試体

変化が複雑になる，そこで，コンクリートの熱伝導 率の温度による変化を定量的に把握するため, 熱伝 導率測定を行なうことにする.

測定は, 円柱供試体の定常温度分布における温度 勾配から熱伝導率を求める, いわゆる円筒法 ${ }^{22}$ を 用いて行なった。測定に供したコンクリート円柱供 試体を図-5に示す。この供試体は，その中心軸上に 全長にわたって直径 $15.8 \mathrm{~mm}$ の内孔が設けられており, この内孔に挿入した電熱線に流れる電流之電圧およ び熱電対によって得られた温度の值を用いれば，コ ンクリートの熱伝導率が次の式で算定できる.

$$
\lambda=\frac{Q}{2 \pi l\left(T_{1}-T_{2}\right)} \log _{e} \frac{r_{1}}{r_{2}}
$$

ここに,

$\lambda:$ 熱伝導率 $\left(\mathrm{kcal} / \mathrm{mh}^{\circ} \mathrm{C}\right)$,

1 : 円柱供試体の長さ $(\mathrm{m})$,

$Q=E I \times 0.859 \quad(\mathrm{kcal} / \mathrm{h})$,

$E$ : 電圧 $(v 01 t), I \quad:$ 電流(ampere),

$r_{1}, r_{2}$ : 円柱供試体の中心軸から熱電対 1,2 までの距離 (m),

$T_{1}, T_{2}$ ：熱電対 1,2 による温度 $\left({ }^{\circ} \mathrm{C}\right)$

上式で得られる熱伝導率は温度 $T_{1}, T_{2}$ の中間の 温度における熱伝導率とした．実験は 10 体の供試体 を用い，合計200デー夕を得た。なお，供試体製作 に用いたコンクリートは前述のヤング係数測定実験 に用いたものと同一である.

図-6に実験によって求めた熱伝導率 $ん$ と温度 $T$ の関係を示す. 図から, 温度が高くなるに従い, 熱 伝導率が $1{ }^{\circ} \mathrm{C}$ にき約 $0.1 \%$ 割合で低減することが 認められた。この関係を最小 2 乗法によって定式化 すれば，次の式が得られる(図-6中の実線).

$$
\lambda=2.07-0.0023 T
$$

図-7に, 本実験の結果と既往の研究によるコンク リートの熱伝導率測定結果を示す ${ }^{22}-24$ )。これら 
熱伝導率 $\lambda\left(\mathrm{kcal} / \mathrm{mh}^{\circ} \mathrm{C}\right)$

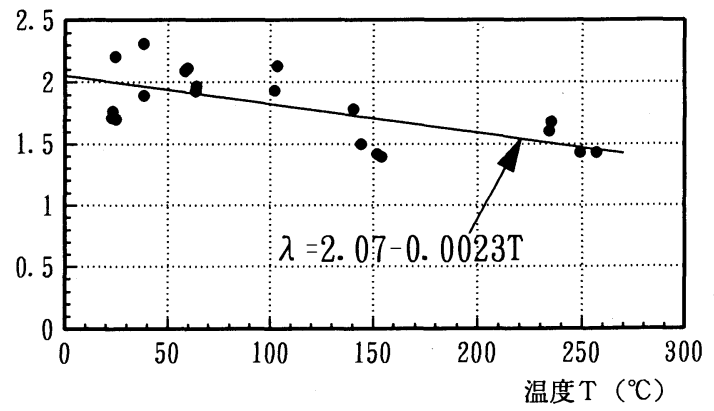

図-6 高温下でのコンクリートの熱伝導率と 温度との関係

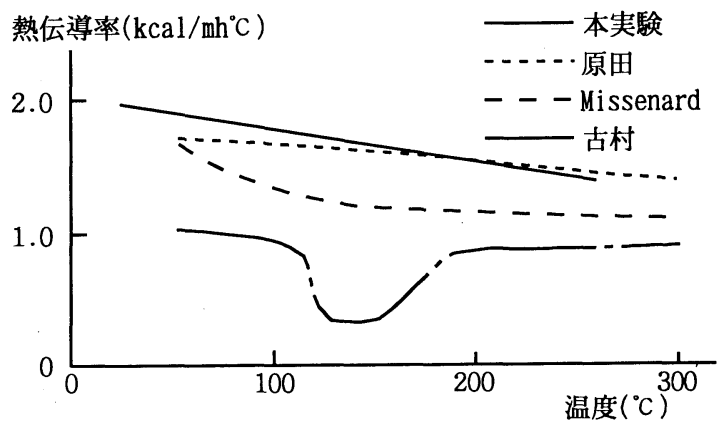

図-7 既往の研究によるコンクリートの熱伝導率

の測定結果は, 古村氏の結果を除いていずれも温度 上昇とともに熱伝導率が低減することを示しており， 本実験と一致する傾向が見られる.

\section{3. 埋め込み鉄筋モデルによる熱伝導・温度 応力解析}

\section{(1)埋め込み鉄筋モデル}

一般に，鉄筋コンクリートや合成構造などのコン クリート構造物は, 主鉄筋や鋼板, 形鋼などの主鋼 材の他に，スターラップ，ずれ止め等多数の鋼材を 内蔵している. そして鋼材の熱伝導率はコンクリー トのそれの数十倍あるため, 鋼材の量, 位置, 方向 等の温度特性に及ぼす影響は無視できない.

通常，コンクリート構造物を有限要素法で解析す る際には，鋼材に沿って要素分割を行なう離散鉄筋 モデルがよく用いられる. しかしながら鋼材配置に よって要素分割が制約を受ける離散鉄筋モデルによ る解析では，いびつな要素形状の採用や要素数, 節 点数の増大を余儀なくされる.

そこでその改善のために, 要素内の任意の位置に 鉄筋を挿入可能な埋め込み鉄筋モデル ${ }^{15}$ (図-8）が 提案されている. このモデル，要素内に㨂入され

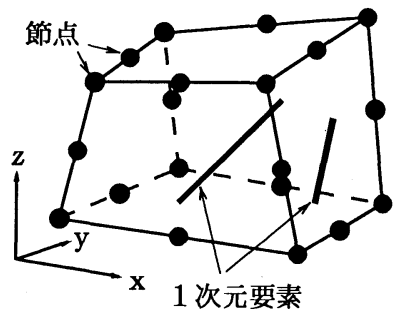

図-8 埋め込み鉄筋モデル

た鋼材の影響を，要素内での位置及び方向を考慮し て評価するものであり，その主な特徴は次の 2 点で ある.

(1)鋼材とコンクリートの複合体の挙動を正確に追 跡可能である.

(2)鋼材の配置が，要素分割に影響を及ぼさないた め, 鋼材配置に依らない自由な要素分割が可能 亡なり, 従来の離散鉄筋モデルに比べて要素数, 節点数を大幅に減らすことが可能となる.

ただし，本モデルでは要素内の鋼材とコンクリー 卜は完全に付着していると仮定し，両者の相対変位 （すべり）を無視する.

このモデルのコンクリート構造物への適用に関す

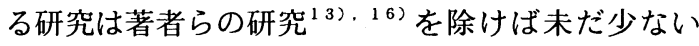
状況にある.ここでは，鉄筋とコンクリートの複合 構造体の熱伝導・温度応力問題をより忠実に解明す るため, 埋め込み鉄筋モデルを拡張・応用し，熱伝 導率やコンクリートの弾性係数の温度依存性を考慮 し得る一般的な 3 次元有限要素解析の定式化を試み, 以下にその骨子を述べる.

\section{(2)熱伝導解析法}

一般に，ガラーキン法による有限要素法を用いて 空間について離散化された熱伝導方程式は次の式で 表わされる.

$$
[\Lambda]\{T\}+[C]\{T\}-\{F\}=\{0\}
$$

ここに,

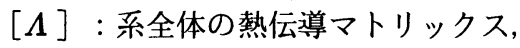

[C] : 系全体の熱容量マトリックス,

$\{F\}$ : 系全体の熱流速ベクトル,

$\{T\}$ : 系全体の節点温度ベクトル,

$\{0\}=\{0, \cdots, 0\}^{T}$

ここに示すマトリックス $[\Lambda],[C]$ およびベクト ル $\{F\}$ は， それぞれ各要素の熱伝導マトリックス [ג]，熱容量マトリックス $[c]$ および熱流速べク トル $\{f\}$ を，系の全要素について足し合わせたも 
のである.

ここで, 鋼材を有するコンクリート構造物の熱伝 導挙動を簡易に解析するために，埋め込み鉄筋モデ ルを拡張・応用する.

埋め込み鉄筋モデルでは, 鉄筋, ずれ止め等の鋼 材はコンクリートを表わすアイソパラメトリック要 素内の所定の位置にある 1 次元要素とみなされ，そ の温度は, 埋め込まれた要素の形状関数によって規 定される.この考え方に立てば，鋼材 $j$ の熱伝導 マトリックス $[\lambda,]_{j}$ および熱容量マトリックス $[c .]_{j}$ は1次元積分を用いて次のように定式化する ことができる.

$$
\begin{aligned}
{[\lambda,]_{j} } & =\int_{L_{s j}} A s_{j}[B]^{T}\{R\}_{j}^{T}\{R\}_{j}[B] d L \\
{[c]_{j} } & =\int_{L, s_{j}} c s_{s j} A s_{s j}\{N\}^{T}\{N\} d L
\end{aligned}
$$

ここに,

$\lambda_{s j}, \rho_{s j}:$ 鋼材 $j$ の熱伝導率および密度,

$c_{s j}, A_{s \mathrm{j}}, L_{s j}:$ 鋼材 $j$ の比熱, 断面積お よび全長

式(5)および 式(6)中の勾配マトリックス $B]$ およ び形状関数 $\{\boldsymbol{N}\}$ は，コンクリートを表わす 20 節点 アイソパラメトリック要素のものと同一である. ま た， ベクトル $\{R\} ;$ ～は鋼材 $j$ の挿入される向きを 表わす方向余弦べクトルであり, 次の式で表わされ る.

$$
\{R\}_{j}=\left\{\cos \phi_{x j}, \cos \phi_{y j}, \cos \phi_{z j}\right\}
$$

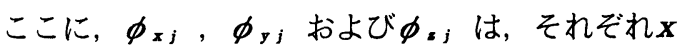
軸, $y$ 軸および $z$ 軸之鋼材 $j$ のなす角である.

$m$ 本の鋼材 ( $j=1 \sim m$ )が埋め込まれたアイソ パラメトリック要素全体の熱伝導マトリックス[ $\lambda]$ および熱容量マトリックス $[c]$ は, アイソパラメト

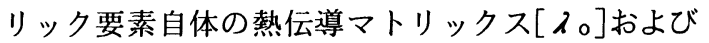
熱容量マトリックス $[c$ 。]に, 式(5)および式(6)で 表わされるm 本の鋼材 $(j=1 \sim m)$ のマトリック ス $[\lambda,]_{j}$ および $[c,]_{j}$ を足し合わせたものとすれ ば良く，それぞれ次の式で表わされる.

$$
\begin{aligned}
& {[\lambda]=\left[\lambda_{0}\right]+\sum_{j=1}^{\mathbb{m}}[\lambda,]_{j}} \\
& {[c]=\left[c_{0}\right]+\sum_{j=1}^{m}\left[c_{s}\right]_{j}}
\end{aligned}
$$

さて, 非定常熱伝導方程式(4)を解くに当たって は時間について離散化する必要がある．そこで時間 について離散化する手法としてクランク・ニコルソ
ン法を採用する．その際，対象とするコンクリート や鋼材の熱伝導率は温度依存性を持っており，その ため熱伝導マトリックス $[\Lambda]$ が温度の関数となり, 式(4)は非線形亡なる。 そこで，本解析では式(4)を 解く際に, 各時間ステップtにおいて熱伝導マトリ ックス $[\Lambda]$ を修正し，次の時間ステップ $t+\Delta t$ の 節点温度べクトル $\{T(t+\Delta t)\}$ が収束するまで繰り 返し計算を行なう，いわゆる単純繰り返し代入 法 $^{25)}$ を採用することとした.

\section{(3)温度応力解析法}

ここでは，（1）節で提案した埋め込み鉄筋モデル の温度応力解析への拡張適用を行なう.

一般にガラーキン法を用いて離散化された温度応 力解析の基礎式は次の式で表わされる.

$$
[K]\{d\}+\left\{F_{t}\right\}=\{0\}
$$

ここに,

$[K]$ : 系全体の剛性マトリックス,

$\left\{F_{t}\right\}$ ：系全体の温度ひずみによる見かけの節点 荷重ベクトル,

$\{d\}$ : 系全体の節点変位ベクトル ここに示すマトリックス $[K]$ およびベクトル $\left\{F_{t}\right\}$ は, 各要素の剛性マトリックス $[\boldsymbol{k}]$ および温 度ひずみによる見かけの節点荷重べクトル（以後, 温度ひずみ節点荷重べクトルと略称する） $\left\{f_{t}\right\}$ を それぞれ, 系の全要素について足し合わせたもので ある.

要素の内の一つについて着目した場合, $m$ 本の 鋼材 $(j=1 \sim m)$ を埋め込まれたアイソパラメトリッ ク要素全体の剛性マトリックス $\boldsymbol{k}]$ および温度ひず み節点荷重ベクトル $\left\{f_{t}\right\}$ は， アイソパラメトリッ ク要素自体の剛性マトリックス $[\boldsymbol{k}$ 。 $]$ および温度ひ ずみ節点荷重べクトル $\left\{f_{t}\right.$ o $\}$ に，鋼材のマトリック ス $\left[\boldsymbol{k}_{\mathrm{s}}\right]_{\mathrm{j}}$ およびベクトル $\left\{\boldsymbol{f}_{\boldsymbol{t}}\right\}_{j}$ ）を足し合わせた ものとすれば良く，それぞれ次の式で表わされる.

$$
\begin{array}{r}
{[k]=\left[k_{\circ}\right]+\sum_{j=1}^{\mathbb{m}}\left[k_{s}\right]_{j}} \\
\left\{f_{t}\right\}=\left\{f_{t \circ}\right\}+\sum_{j=1}^{\mathbb{E}}\left\{f_{t s}\right\}_{j}
\end{array}
$$

\section{4. 鉄筋コンクリートはりおよび鋼・コンク リート合成はりの温度特性}

高熱負荷を受ける鉄筋コンクリートはりおよび鋼 ・コンクリート合成はりの挙動を解明するとともに, 前述の有限要素解析の有用性を検証するため, 100 
${ }^{\circ} \mathrm{C} \sim 1000^{\circ} \mathrm{C}$ 領域を対象とした加熱実験を行なう. 比較的低温域 $\left(100^{\circ} \mathrm{C} \sim 200^{\circ} \mathrm{C}\right)$ につては温度制御が 容易な電熱線による加熱実験結果を活用する。この 種の実験内容についてはその成果の一部を既に文献 （13）で報告しているので，ここでは詳細を省き必要 事項のみ略述する. 一方, $200^{\circ} \mathrm{C} \sim 1000^{\circ} \mathrm{C}$ にいて はガスバーナーによる加熱実験で対処するものとす る. すなわち, この場合 $600^{\circ} \mathrm{C}$ 以下では温度制御が 必ずしも安定しないが, 火力が強い装置であるため, 加熱温度を常温から $1000^{\circ} \mathrm{C}$ 範囲まで取り扱うこと が可能となる. いずれの場合も測定は，はり内部の 温度分布，ひずみ分布を対象とする.

\section{(1)加熱実験の概要}

電熱線による加熱実験に供した鉄筋コンクリート はり（ＲＣはり）および鋼・コンクリート合成はり （T S C 合成はり)の供試体はそれぞれ2体，合計4体 であり，図-9に示す諸元を有する．T S C 合成はり は底部鋼板, 圧縮鉄筋, 立体卜ラス型ジベルおよび コンクリートからなる合成はりであり，その寸法諸 元については鉄筋コンクリートはりと曲げ耐力およ びせん断耐力がほぼ等しくなるように決定した．ま た，ガスバーナーによる加熱実験に供したT S C 合 成はり供試体(2体)を図-10に示す.ガスバーナーに よる加熱実験ではこのT S Cはりに加えて, 同寸法 の無筋コンクリートはりも実験に供した.これらの はり供試体のコンクリートの示方配合は前述の材料 定数測定試験に用いたものと同じである.

電熱線による加熱実験は, 図-11に示すような電 熱線を利用して熱放射効果を極力回避できるような 加熱装置を考案し，それを用いて供試体を圧縮鉄筋 側のコンクリート面から加熱し，内部温度とひずみ を測定した。供試体は加熱装置に上下逆に配置され， 電熱線によって熱せられた熱気が供試体の圧縮鉄筋 側（加熱装置に配置された状態での下面側）に触れ ることによって供試体に熱が伝えられる．加熱範囲 とその反対側の面以外はすべて断熱材により断熱さ れている. 加熱温度は加熱開始時の常温 $\left(\right.$ 約 $\left.14^{\circ} \mathrm{C}\right)$ か ら, 加熱時間に比例して温度上昇させ, 約 5 時間て $200^{\circ} \mathrm{C}$ に達して, その後は $220^{\circ} \mathrm{C}$ 前後でほぼ安定させ た.

ガスバーナーを用いた加熱実験装置を写真-2に示 す.

電熱線を用いた加熱実験では，加熱装置の限界に より最高加熱限度を $200^{\circ} \mathrm{C}$ としが，ガスバーナー による加熱実験では，コンクリート構造物が火災に

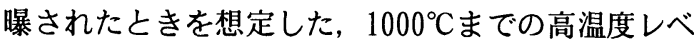
ルを対象とする．実験に用いたガスバーナーは燃料
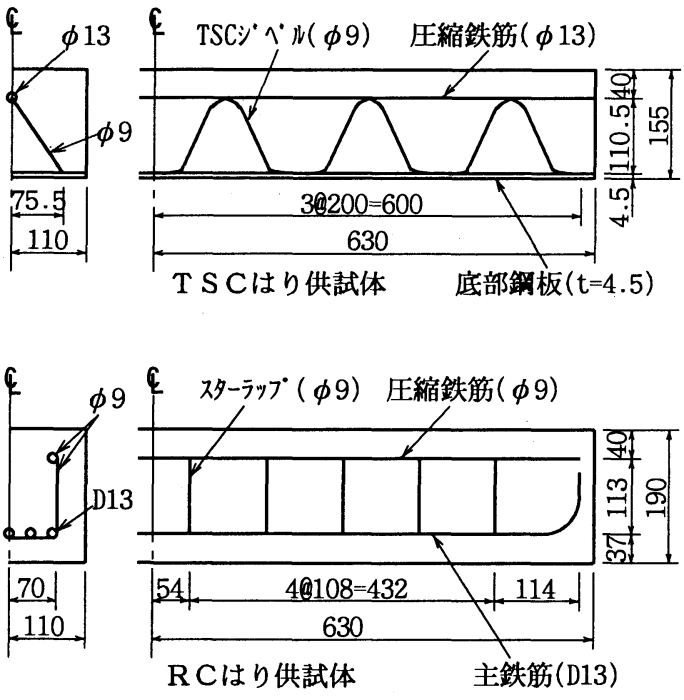

(単位: mm)

図-9 電熱線による加熱実験に用いたはり供試体
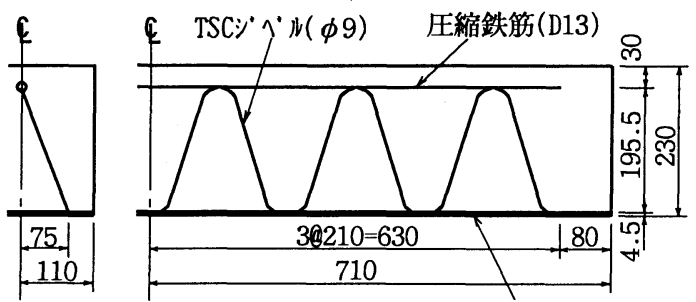

(単位: $\mathrm{mm}$ )

底部鋼板 $(t=4.5)$

図-10 ガスバーナーによる加熱実験に用いた T S Cはり供試体

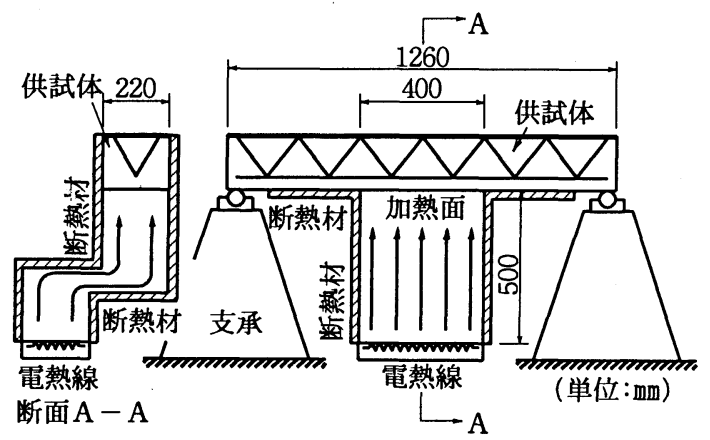

図-11 電熱線を用いた加熱装置

として L P ガスを用い，燃焼ガスを供試体表面の加 熱面に直接吹き付けることによって，はりの加熱を 行なう. 加熱温度は, 室温 $\left(\right.$ 約 $\left.10^{\circ} \mathrm{C}\right)$ から約 $16^{\circ} \mathrm{C} /$ 分 のペースで直線的に上げていくこととした．その際， 
表-2 解析に用いた諸定数

\begin{tabular}{|c|c|c|c|c|c|c|}
\hline & $\begin{array}{l}\text { 熱伀導率 } \\
\mathrm{kcal} / \mathrm{mh}^{\circ} \mathrm{C}\end{array}$ & $\begin{array}{c}\text { 熱容量 } \\
\mathrm{kcal} / \mathrm{m}^{3}{ }^{\circ} \mathrm{C}\end{array}$ & $\begin{array}{l}\text { 熱伝達係数 } \\
\mathrm{kcal} / \mathrm{m}^{2} \mathrm{~h}^{\circ} \mathrm{C}\end{array}$ & \begin{tabular}{|c|} 
線膨張係数 \\
$\mathrm{x} 10^{-6} /{ }^{\circ} \mathrm{C}$ \\
\end{tabular} & $\begin{array}{l}\text { ヤング係数 } \\
\mathrm{x} 10^{5} \mathrm{kgf} / \mathrm{cm}^{2} \\
\end{array}$ & 术アソ比 \\
\hline コツクリート & $2.07-0.0023 \mathrm{~T}^{*}$ & 420 & \multirow{2}{*}{10.0} & 10.0 & $3.27 \mathrm{e}^{-0.00178 \mathrm{~T}^{*}}$ & 0.192 \\
\hline 鋼材 & $60-0.06 \mathrm{~T}^{*}$ & 890 & & 11.7 & 21.0 & 0.3 \\
\hline
\end{tabular}

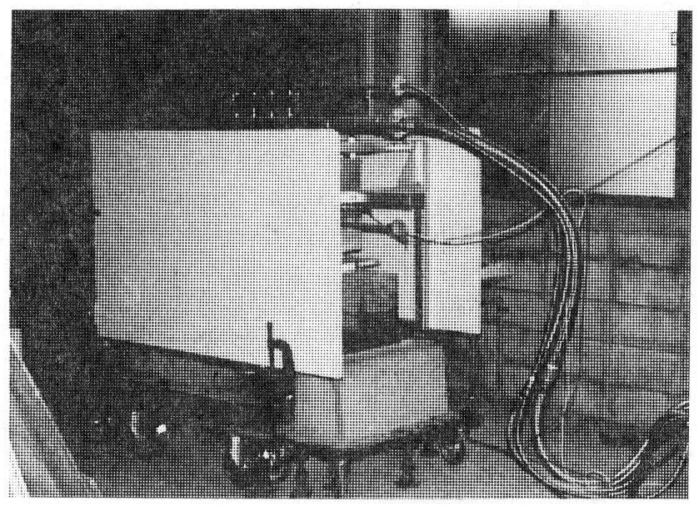

写真-2 ガスバーナーを用いた加熱実験装置

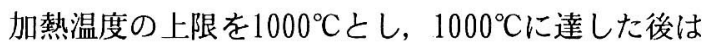
一定の温度を保つこととした。

なお，供試体内の温度や加熱温度の測定には K夕 イプ熱電対（測定最高温度 $1200^{\circ} \mathrm{C}$, 誤差土0.75\%以 内）を用いた。

\section{(2)解析の概要}

まず解析で用いた諸定数を表-2に示す．空気と固 体との熱伝達係数, 鋼材の諸定数は既往の文 献 ${ }^{263}$.27) の值を, コンクリートの諸定数の内, 熱 容量および線膨張係数は, 既往の文献 ${ }^{242,263}$ の值 を採用した．コンクリートのヤング係数および熱伝 導率は, 前述の高温下での測定実験による值を用い た. ただしコンクリートの熱容量 $\rho \cdot c$ とポアソン 比עについては高温下でのデータが得られなかっ たことと $\rho \cdot c$ とע の值を変化させても計算結果 にあまり差が見られないことを考え合わせ,ここで は常温時の值 $\rho \cdot c=420\left(\mathrm{kcal} / \mathrm{m}^{3} \mathrm{C}\right), \nu=0.192$ を 用いた。

ただしガスバーナーによる加熱実験では，ガスバ 一ナーのノズルから吹き出される燃焼ガスが供試体 表面に直角に吹き付けられる，いわゆる衝突噴流之 呼ばれる境界条件よなっている．このため，燃焼力゙ スと供試体表面との間の熱伝達係数を燃焼ガスの流 速を考慮して修正した ${ }^{28)}$ 。室内などでの無風状態 での熱伝達計数は通常 $6 \sim 10\left(\mathrm{kcal} / \mathrm{m} 2 \mathrm{~h}^{\circ} \mathrm{C}\right)$ とされて いる．本装置では加熱温度を高くするためには，よ り多くの燃料を燃焼させる必要があり，供試体表面 に吹きつける燃焼ガスの流速が上がることになる.
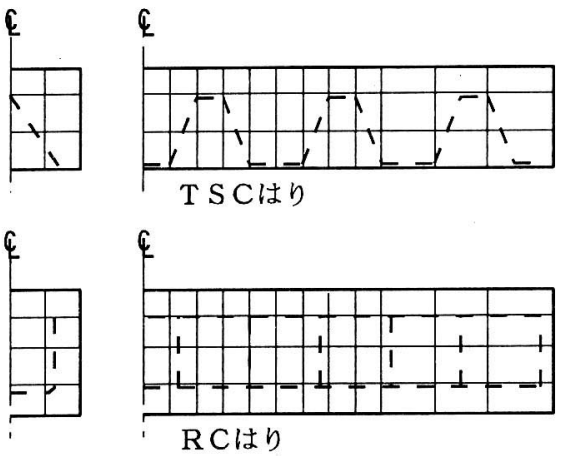

図-12 要素分割（電熱線による加熱実験）
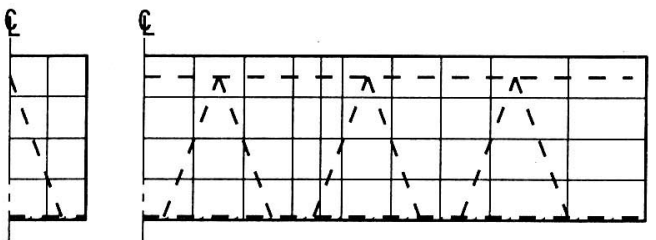

図-13 要素分割（ガスバーナーによる加熱実䮦）

そこで， ガスの流速を測定し，熊田らの算定式 ${ }^{283}$ を用いて衝突噴流境界条件での熱伝達係数を定め, 解析に用いた。これによると熱伝達係数は加熱温度 $500^{\circ} \mathrm{C}$ で無風時の約 1.9 倍, $1000^{\circ} \mathrm{C}$ で無風時の約 4.0 倍となる．従ってガスバーナーによる加熱状態は, 無風状態での加熱に比べて加熱を受ける境界面での 熱の流入量がかなり多くなり，T S C 合成はりにと ってより㛜しい条件下での加熱となる.

前述の実験で求めた熱伝導率は常温から $250^{\circ} \mathrm{C}$ 程 度までの温度範囲のものであるのに対し，ガスバー ナ一による加熱実験ではコンクリートの温度が 250 ${ }^{\circ} \mathrm{C}$ を越し $400^{\circ} \mathrm{C}$ 程度まで達する領域を対象とするも

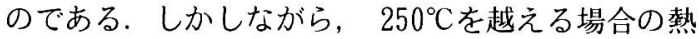
伝導率は未だ究明されていないため，一応，式(3) が適応できるものと仮定して解析を進めるものとす る.

解析に用いた 3 次元要素分割を図-12および図-13 に示す. 図に示すように，埋め込み鉄筋モデルの採 用により要素分割は鋼材配置によらず自由に行なう ことができる.ここでは供試体形状の対称性を考虑

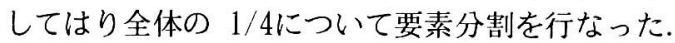
要素数および節点数は，それぞれ，電熱線による加 
熱実験では T S C はり供試体が72および521， R C はり供試体が96および661， ガスバーナーによる加 熱実験のT S C はり供試体は 80および557である. なお, 熱伝導解析の時間差分の際の微小時間増分 $\Delta t$ は，電熱線による加熱実験では10min. とし， ガスバーナーによる加熱実験では3min. とした.

\section{(3)結果および考察}

\section{a)温度分布}

図-14(a, b)に電熱線を用いた加熱実験による圧縮 鉄筋を通る断面における温度分布の実験結果および 解析結果を示す(文献(13)の解析例では, 温度依存 性が考慮されていない). また，図-15(a,b)にはガ スバーナーを用いた加熱によるものを示す．図中の 実線は解析結果であり, 黒丸(の) とその横の数值は 熱電対埋め込み位置とその点での実測温度を示す. 実験值で括弧内の数值は 2 体目の供試体のものであ る. 但し, 図-15(b)（ガスバーナーによる無筋コン クリートはりの加熱) には解析結果のみが示されて いる. これは無筋コンクリートでは加熱開始後10分 以内の時点で加熱面全体にわたって爆裂が生じ実験 の継続が不能となったためである.この爆裂現象に ついてはひずみ分布についての考察と併せて後述す る.

圧縮鉄筋の温度は電熱線による加熱では加熱開始 後 6 時間で T S C はり, R C はり共に $80^{\circ} \mathrm{C}$ 前後に, またガスバーナーによる加熱では加熱開始後 60 分で 最高 $250^{\circ} \mathrm{C}$ とっててる。はり内部の最高温度は, 電熱線による加熱では $80 \sim 100^{\circ} \mathrm{C}$, ガスバーナーに よる加熱では $400^{\circ} \mathrm{C}$ 台に達している. 温度勾配は加 熱範囲付近の部位では急であり, 加熱範囲から遠ざ かるにつれて緩やかになっている.このような非定 常熱伝導の一般的傾向は解析結果によって良く表わ されている. 解析結果は実験値と比較して若干の誤 差が認められるものの，全般的に実験挙動をよく追 跡できており，埋め込み鉄筋モデルがコンクリート 合成構造の熱伝導解析に十分適用し得ることが確か められた。

なお，解析值と実験値との間の誤差の原因として は,

(1)加熱装置内の熱気温度の場所による不均一

(2)加熱装置と供試体との間の熱放射の影響

(3)供試体表面の粗さが熱伝達係数に与える影響

（特にガスバーナーによる衝突噴流の場合） 等が考えられる．また，後述するように，ガスバー ナーによる加熱実験では温度応力によってコンクリ 一トにひび割れが発生した．それにともなう，

(4)ひび割れに沿った水分の移動

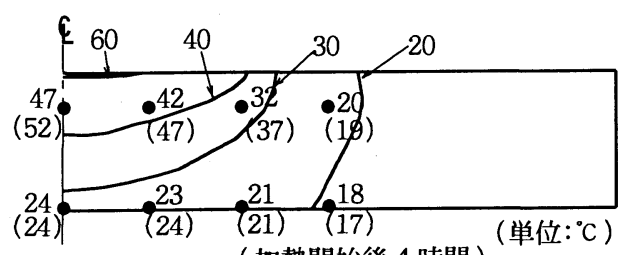

（加熱開始後 4 時間）

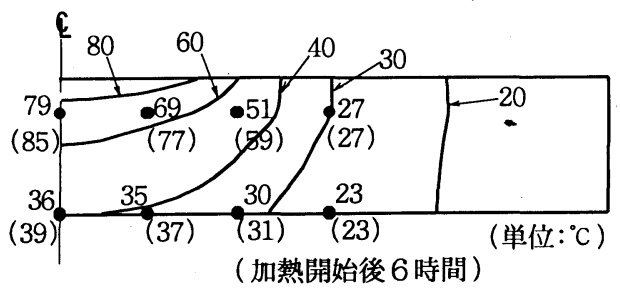

図-14(a) T S Cはりの温度分布 （電熱線による加熱実験）

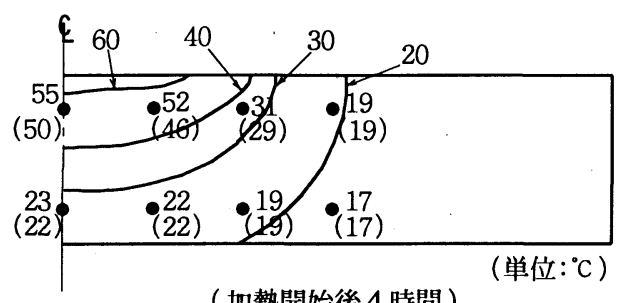

（加熱開始後 4 時間）

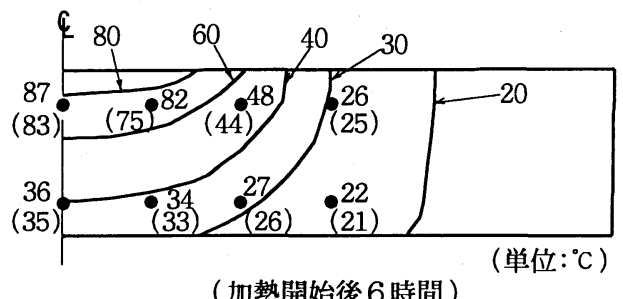

図-14(b) RCはりの温度分布

（電熱線による加熱実験）

(5)衝突噴流の，ひび割れを介してのはり内部への 浸透

等も誤差の原因として考えられる.

電熱線による加熱結果(図-14(a, b))によれば，T S C はりとR C はりとの間には，両者の鉄筋量がほ ぼ等しいため大きな差は認められない，T S Cはり はR C はりに比べて主鉄筋のかぶりの分だけ桁高が 小さくなっている．しかし本実験の加熱継続時間並 びに加熱温度範囲では，コンクリートの断熱効果が 十分大きく, 主鉄筋側表面の温度が少ししか上昇し ないため，かぶりの有無による桁高の違いの影響は 

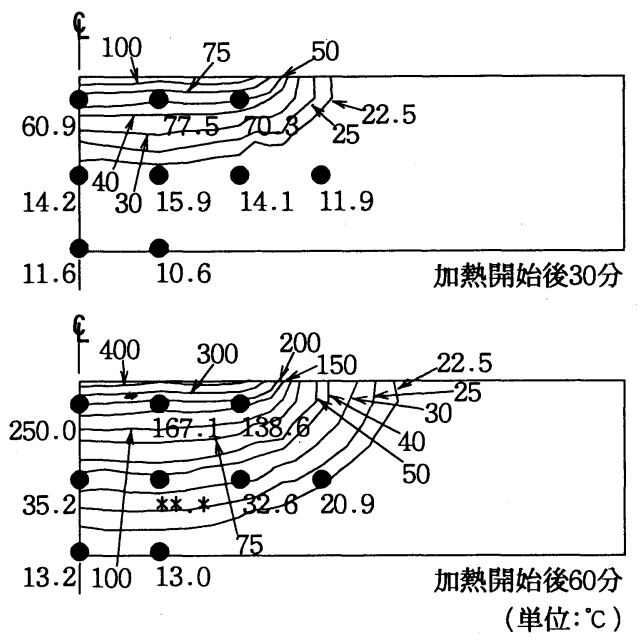

図-15(a) T S Cはりの温度分布 （ガスバーナーによる加熱実験）
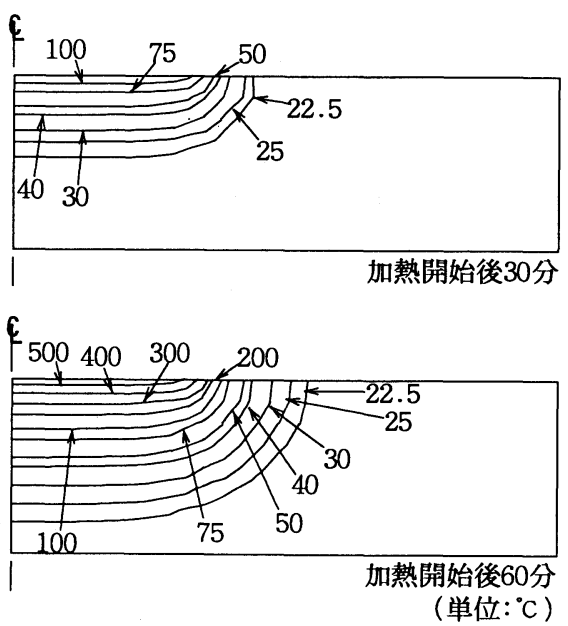

図-15(b) 無筋コンクリートはりの温度分布 （ガスバーナーによる加熱実験）

明瞭には現れなかった.

また，ガスバーナーによる加熱の解析結果(図-15 (a,b))によれば, 無筋コンクリートはりの温度勾配 はT S Cはりの温度分布よりも急となっており, 加 熱面付近の温度は $100^{\circ} \mathrm{C}$ 程高くなっている(加熱開始 後60分の図を参照). これは大きな熱伝導率を持つ 鋼材の影響である.このことは熱が未だ圧縮鉄筋ま で達していない加熱開始後15分の時点でT S Cはり および無筋コンクリートはりの温度分布にほとんど 差がないことからも裏付けられる.
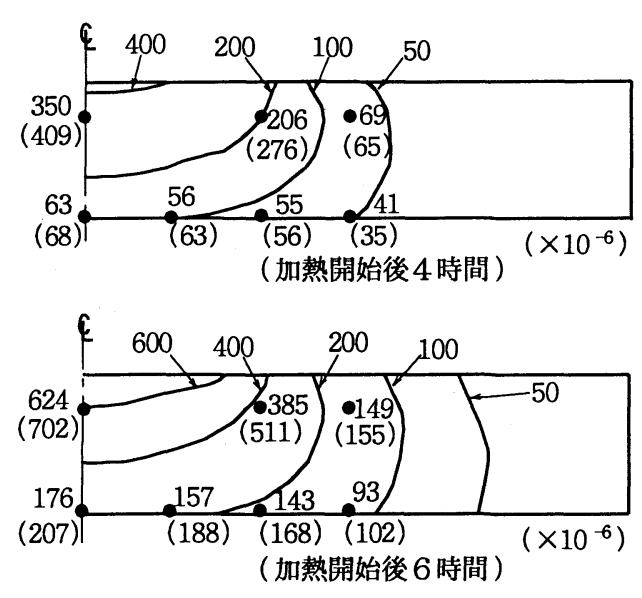

図-16(a) T S Cはりのスパン方ひずみ分布 （電熱線による加熱実験）
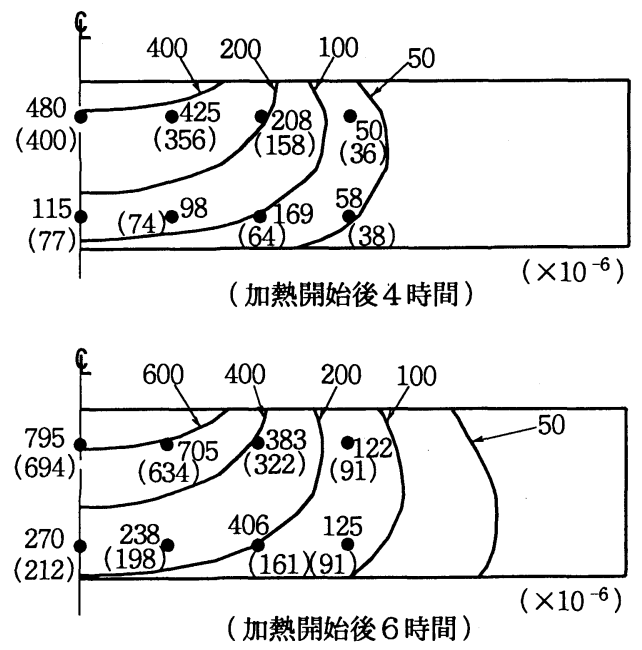

図-16(b) RCはりのスパン方向ひずみ分布 （電熱線による加熱実験）

\section{b)ひずみ分布}

次に，図-16(a,b)に電熱線による加熱実験による スパン方向ひずみ分布の実験結果および解析結果を 示す. また，図-17(a, b)にガスバーナーによる加熱 実験によるものを示す，実線は解析值を，黒丸(の) とその横の数値はひずみゲージの貼付位置とそれに よる測定值を示す（但し，爆裂現象発生のため無筋 コンクリートは解析值のみ). 実験值で括弧内の数 値は2体目の供試体のものである. なお，正値は引 張を表わす. 図から明らかなように, この種の実験 においては載荷実験などに比較して, 本来, 供試体 

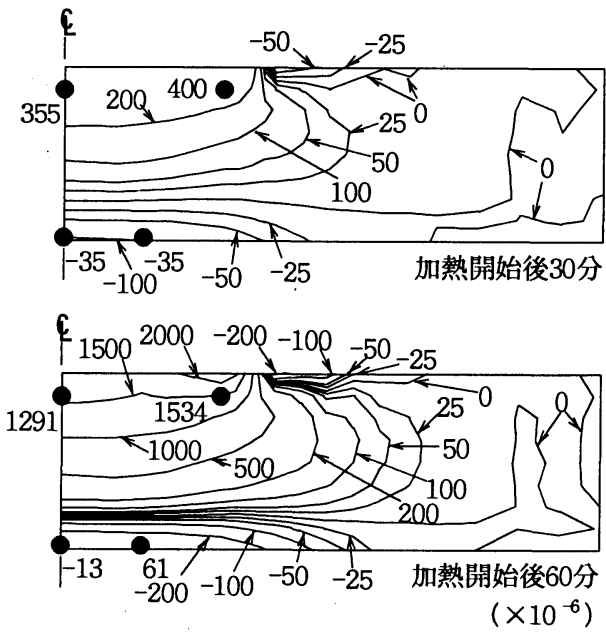

図-17(a) T S Cはりのひずみ分布 （ガスバーナーによる加熱実験）
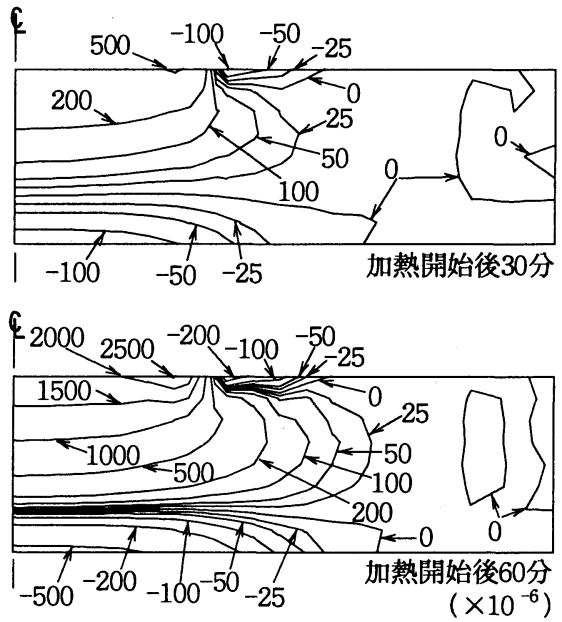

図-17(b) 無筋コシクリートはりのひずみ分布 （ガスバーナーによる加熱実験）

間の測定値のばらつきも大きく，従って実験値と解 析値の一致を見るのは極めて困難である．それに対 して本実験で，多くの測点で実験値と解析值との誤 差を $20 \%$ 以内に抑えることができていることは評価 に值すると考えられる．以上より，埋め込み鉄筋モ デルを用いた本解析法は，複雑に鋼材が配置された 合成構造に対しても要素分割等の取り扱いが簡便で あり，かつ; 比較的精度の良い解が得られることか ら, 有用性は高い之判断される。

しかしながら，ガスバーナーによる加熱実験結果 （図-17(a))に着目すれば，底部鋼板については，加 熱開始後 15 分では解析值と実験值が一致しているも のの, 加熱開始後60分では両者の差は著しい。これ
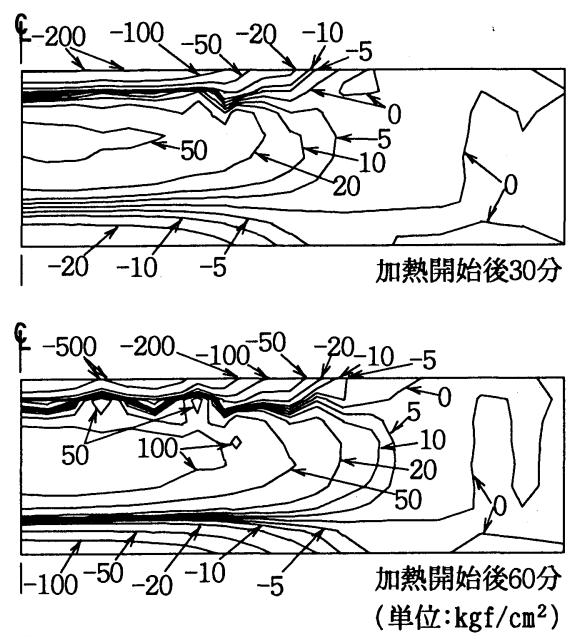

図-18 T S Cはりの応力分布 （ガスバーナーによる加熱実験）

は急激な加熱により，はりの中間レベル高さの付近 で引張応力によるひび割れが生じた結果によるもの と考えられる. その根拠の一つとして 図-18に示す スパン方向応力の分布を見れば，加熱開始後30分で, はり中央部の一部に $50 \mathrm{kgf} / \mathrm{cm}^{2}$ 以上の引張応力が生 じていることが挙げられる. すなわち，この時点で コンクリートに引張ひび割れが生じたと判定できる ことになる.このひび割れ発生によってコンクリー 卜の引張抵抗力が低減し, 応力が解放され, それに 伴い鋼板の圧縮ひずみが低減されたもの之考えられ る. 高温下においてコンクリートのひび割れを考慮 し得る非線形解析法の確立が望まれるが，これは今 後の研究課題としたい.

図-17(a,b)に示すT S C はりと無筋コンクリート はりのひずみ分布によれば，ひずみ分布の傾向は両 者ともほぼ同じであるが，最大ひずみは無筋コンク リートの方が大きめの值となっている．この差は温 度分布の違い(図-14(a,b)参照)で説明できるが，コ ンクリートと鋼材の線膨張係数の違いによる影響屯 原因として挙げられる.

ところで，前述したようにガスバーナーによる無 筋コンクリートの加熱実験では加熱開始後約10分以 内の時点で加熱面全体に爆裂が生じた. この爆裂に よるはりの破壊ははり表面から $5 \mathrm{~cm}$ 深さにまで及 ぶものであった．爆裂の原因としては加熱による間 隙の圧力の増加や蒸気の急速な流れ等が従来から指 摘されている ${ }^{29)}$. 図-15(a,b)および図-17(a,b)に 示す温度分布およびひずみ分布を比較しても，T S Cはりと無筋コンクリートはりとの間には最大温度 や最大ひずみの違いは20\%程度認められるものの， 
温度およびひずみの分布の傾向にはほとんど差が認 められない. 即ち, 本解析の結果では爆裂現象の発 生を予測することは不可能であると言わざるを得な い. しかし一般に爆裂現象は，温度およびひずみの 分布だけではなく，水分の分布，骨材の組成や，ポ アサイズの影響を受けると言われており ${ }^{29)}$ ，爆裂 現象の発生まで正確に予測するためにはこれらを含 めて考慮した複雑な解析が必要となる. 本実験の結 果を見る限りでは，T S C はりと無筋コンクリート はりは同じ加熱条件であったにも関わらずT S C は りは 2 体亡も爆裂現象から免れており，コンクリー ト中の鋼材の存在が爆裂の発生防止に何らかの寄与 をしたと考えるべきである.

\section{5.まとめ}

本研究は $1000^{\circ} \mathrm{C}$ 達する高温下に曝された, R C はりおよびT S C 合成はりの温度特性を明らかにす ることを主目的とし，

(1)高温下におけるコンクリートのヤング係数および 熱伝導率測定実験を行ない，これらの材料定数やそ の温度依存性を明らかにするとともに，

(2)埋め込み鉄筋モデルによる熱伝導・温度応力解析 手法を提案して, その有用性を実験結果との比較に より実証したものである.

本研究により得られた成果を以下に要約する.

（1）高温下のコンクリートのヤング係数を精度良 く定量的に測定することができる計測装置を試作し， 標準的な普通コンクリートを対象とした実験を行な った. その結果, 高温下におけるコンクリートのヤ ング係数は $100^{\circ} \mathrm{C}$ で常温時の約 $70 \%, 420^{\circ} \mathrm{C} て ゙$ 約 50 \%程度まで低減することが明らかにされ，そのヤン グ係数の温度依存性の評価式を導くとともに, 高温 下でのヤング係数と冷却後のヤング係数との間に差 があること等の知見を得た.

（2）さらに，コンクリートの熱伝導率についても 温度依存性の評価式を実験結果から定め, $1^{\circ} \mathrm{C}$ 温 度上昇につき約 $0.1 \%$ の割合で低減することが明ら かとなった。

（3） R Cはり, T S C 合成はりの電熱線およびガ スバーナーによる 2 種類の高温加熱実験を行なった. これにより, 圧縮鉄筋の最高温度は, 電熱線による 加熱(加熱継続時間6時間, 最高加熱温度約 $220^{\circ} \mathrm{C}$ )で は $80^{\circ} \mathrm{C}$ 前後に， ガスバーナーによる加熱(同60分, $\left.1000^{\circ} \mathrm{C}\right)$ では約 $250^{\circ} \mathrm{C}$ 達することなど，これらのは りの高温下での温度特性に関する種々の知見を得る とともに，実験結果との比較により，提案した埋め 込み鉄筋モデルを用いた解析法の有用性を実証した.

\section{参考文献}

1）田辺忠顕，原田晃，内田敏久：ダム嵩上げ時の温度応力 の実測と温度応力検討方法についての提案, 土木学会論 文報告集，第333号, pp. 185-196, 1983.

2）森本博昭, 小柳洽 : コンクリート構造物の温度ひび割れ 予測に関する研究，土木学会論文報告集，第338号，pp. 197-206, 1983.

3）たとえば, 木村克彦，小野定，後藤貞雄，江渡正満 : プ レクーリングによるマスコンクリート温度ひび割れて制御 効果の解析, 構造工学論文集, Vol. 35A, pp. 1129-1136, 1989.

4）たとえば，田辺忠顕，山川秀次，渡辺朗：パイプクーリ ングにおける管断面の熱伝達率の決定ならびに冷却効果 の解析, 土木学会論文報告集, 第343号, pp. 171-179, 1984.

5）秋野金次，渡部征男：コンクリート製原子炬格納容器の 設計法, コンクリート工学, Vol. 19, No. 7, pp. 79-87, 1981.

6) 吉田一: 原子炬建屋の熱応力解析, コンクリート工学, Vol. 22, No. 3, pp. 66-69, 1984.

7）阿部博俊, 青柳征夫, 田辺忠顕 : プレストレストコンク リート压力容器の温度クリープ性状とクリープ解析につ いて，コンクリートジャーナル，Vol. 12， No.6，pp.4757, 1974.

8）たとえば，塩屋繁松，川股重也，高山誠，秋山宏，金井 頼利 : 有限要素法を用いた原子炉圧力容器のクリープ解 析, コンクリートジャーナル, Vol. 12, No. 6, pp. 111126, 1974.

9）加藤宗明 : 原子炉関連施設とコンクリート，コンクリー 卜工学, Vol. 27, No. 4, pp. 21-28, 1989.

10）たとえば，山本康榑，杉正：L NG地下タンクの設計法, コンクリート工学, Vol. 19, №.7, pp. 72-78, 1981.

11）たとえば，横室隆，依田彰彦: 熱を受けたコンクリート 乙鉄筋之の付着強度・压縮強度・ヤング率，コンクリー 卜工学年次論文報告集，Vol.9-1，pp. 169-174，1987.

12）たとえば，小山堯：耐久性診断事例一火災一, コンクリ 一ト工学, Vol. 26, №. 7, pp. 84-88, 1988.

13）太田俊昭，黒田一郎，山口栄輝，日野伸一: 外的温度負 荷を受けるR Cおよび合成構造部材の熱云導および温度 応力特性に関する研究，構造工学論文集，Vol. 37A, pp. 1319-1328, 1991.

14）たとえば，太田俊昭，日野伸一，舆石正己，日向泰山： 立体トラス型ジベルを有する合成版構造の力学特性と設 計法に関する研究，構造工学論文集，Vol. 34A，pp. 297305, 1988.

15) ASCE Committee on Concrete and Masonry Structures, A State-of-the-art report on finite element analysis of reinforced concrete, Task Committee on Finite Element Analysis of Reinforced Concrete Structures, ASCE Spec. Publ., 1981.

16）山口栄輝，太田俊昭, 舆石正己, 川野清 : コンクリート 
構造物の有限要素法解析における埋め込み鉄筋モテルに ついて, 構造工学論文集, Vol. 36A, pp. 305-313， 1990.

17）太田俊昭，黒田一郎，日野伸一：高温下における鉄筋コ ンクリートはりの熱伝導特性と温度応力特性に関する研 究，コンクリート工学年次論文報告集，Vol. 13-1, pp. 333-338, 1991.

18）金津努，中野毅弘，遠藤達巳 : 高温にさらされるコンク リートの物性に関する基䃈的研究，土木学会年次学術講 演概要集, No. 38, pp. 113-114, 1983.

19）岩沢二郎，嵩英雄，佐久田昌治，佐藤忠博：高温にさら された蛇紋岩コンクリートの諸性質その 1 ，建築学会大 会学術講演梗概集, pp. 461-462, 1977.

20）岸谷孝一，嵩英雄，奥山治也，奥野亨： $20 \sim 300^{\circ} \mathrm{C}$ 高温 にさらされたコンクリートの諸性質に関する研究，建築 学会大会学術講演梗概集, pp. 143-144, 1972.

21）嵩英雄, 大野定俊 : 高温下のコンクリートの物性, コン クリート工学, Vol. 22, №. 3, 1984.

22）原田有: 高温度に於けるセメントモルタル及びコンクリ
一トの熱伝導率の変化，建築学会研究報告， No. 18 , 1952.

23) Missenard, A. :Recherches Theoriques et Experimentales sur la Conductivite Thermiquedes Betons, Annales de l'Institut Technique du Batiment et des Travaux Publics, Nos. 211-212, pp. 950-968, 1965.

24）古村福二郎：コンクリートと熱（1），コンクリート工 学, Vol. 17, No. 8, pp. 87-95, 1979.

25）矢川元基, 宮崎則幸 : 有限要素法による熱応力・クリー プ・熱伝導解析, pp. 444-445, サイエンス社, 1985.

26）徳田弘：コンクリートの熱的性質, コンクリート工学, Vol. 22, No. 3, pp. 29-37, 1984.

27）渡辺正紀・佐藤邦彦：溶接工学とその応用, 朝倉書店, p. $163,1965$.

28）日本機械学会：伝熱工学資料改訂第 4 版，pp. 65-66, 日 本機械学会, 1986.

29） U. シュナ㐴”一著，森永繁監訳：コンクリートの熱的性質， 技法堂出版，pp. 124-126，1983.

(1994. 10. 21 受付)

\title{
FUNDAMENTAL STUDY ON THE THERMAL PROPERTIES OF CONCRETE STRUCTURAL MEMBERS UNDER EXTERNAL HIGH TEMPERATURE LOADING
}

\author{
Ichirou KURODA, Shin-ichi HINO and Toshiaki OHTA
}

\footnotetext{
Heat conduction and thermal stress problems of reinforced concrete members and steel-concrete composite members are discussed based on the experimental and theoretical points of view under external high temperature loading condition such as $1000^{\circ} \mathrm{C}$. Finite element analysis using an extended embedded model for reinforcements is presented to solve the three dimensional thermal problems of these members. In addition, the heat conductivity and Young's modulus of concrete are measured under such high temperature.
} 